\title{
The cognitive load of listening activities of a cognitive-based listening instruction
}

\author{
Mehrak Rahimi* and Mehran Sayyadi \\ English Department, Faculty of Humanities, Shahid Rajaee Teacher Training University, \\ Lavizan, 1678815811, Tehran, Iran
}

\begin{abstract}
The aim of this study was to investigate the cognitive load (henceforth, CL) of listening activities of a cognitive-based listening instruction of a recently changed EFL curriculum. 126 $\mathrm{K}-11$ students (male $=62$, female $=64$ ) participated in the study. The quantitative and qualtivative data were collected and analyzed in two phases. In phase 1, the participants were asked to judge the CL of listening activities of their textbook based on the CL measure immediately after completeling the tasks. The scale has 10 items that measure three components of CL including Intrinsic Load (IL), Extraneous Load (EL), and Germane Load (GL). The data were analyzed by Multivariate Analysis of Variance (MANOVA). The result primarily revealed that the general cognitive load of listening activities was rather high and when three kinds of CLs were compared, the GL was found to be higher than IL and EL. Comparing the CL of male and female students revealed that there is a signficant difference between the two groups regarding general CL and both IL and EL; and as the GL of both groups was high, no signficant difference was observed between their GL. In pahse 2 of the study, 14 students participated in a structured interview to express their opinions about the difficulty of listening comprehension. The rate of speech and unintelligibility of the speakers' pronunciation, insufficient technological infrastructures, lack of interest in and negative attitudes towards listening, and limited multidmodal input were among the factors that students felt to contribute to the difficulty of listening comprehension.
\end{abstract}

Keywords: Cognitive load; curriculum change; English; gender; listening

First Received:

17 May 2019

Final Proof Received:

26 September 2019

\section{Revised:}

30 August 2019
Accepted:

5 September 2019

Published:

30 September 2019

How to cite (in APA style):

Rahimi, M. \& Sayyadi, M. (2019). The cognitive load of listening activities of a cognitivebased listening instruction. Indonesian Journal of Applied Linguistics, 9, 382-394. doi: $10.17509 /$ ijal.v9i2.20236

\section{INTRODUCTION}

Listening is a complex cognitive process that plays a key role in language acquisition and development. Listening is one of the four macro language skills (along with speaking, reading, and writing) and "the most widely used language skill in normal daily life" (Martínez-Flor \& Usó-Juan, 2006, p. 29) and communication. Listening is differentiated from hearing (Hornsby, 2013) as hearing is just the perception phase of listening where the sounds are discriminated in an automatic process without the hearer's concentration of effort or attention. Listening, on the other hand, denotes understanding a message that "includes attention, concentration, rate of input, as well as misunderstanding and emotional responses" (Worthington \& Bodie, 2018, p. 70) in the process of communication.

For a long time listening was regarded as the simple act of decoding linguistic forms (identifying words, sentences, intonation contours, etc.) and a passive skill to master by overlearning. By the emergence of cognitive and communicative frameworks, the focus from automatic/linguistic processing of information during listening was shifted to more cognitive, emotional, and behavioral aspects. It is now believed that there are four main orientations involved in listening including (a) receptive, listening is

\footnotetext{
* Corresponding Author

Email: rahimi@sru.ac.ir
} 
receiving what the speaker actually says; (b) constructive, listening is constructing and representing meaning; (c) collaborative, listening is negotiating meaning with the speaker and responding; and (d) transformative, listening is creating meaning through involvement, imagination and empathy (Rost, 2011, pp. 2-4). Listening as an active process is defined as (Vandergrift, 1999, p.168):

a complex active process in which the listener must discriminate between sounds, understand vocabulary and grammatical structures, interpret stress and intonation, retain what was gathered in all of the above and interpret it within the immediate as well as the larger socio-cultural context of the utterance.

The core element of listening is communication and interaction between interlocutors, where in most listening situations the listener takes the dual role of listener/speaker. Research shows that listening comprehension in another language is inherently a very challenging and difficult task (Bacon, 1992; Herron \& Seay, 1991; Vandergrift, 2007). The difficulty of listening comprehension has been attributed to many factors such as the contextual (ESL vs. EFL setting), personal (gender, age), cognitive (background knowledge, short term memory), and emotional (motivation, anxiety) variables (e.g., Ikezawa, et al., 2008; Lau, 2017; Chon \& Shin, 2019).

As a cognitive process, listening involves discrimination, perception, and comprehension phases intermingled with the listeners' motivational and intentional investment. By looking at listening difficulty from a purely cognitive perspective, it can be said that the cognitive processes that take place in brain may act as one main source of difficulty listeners face when they are doing listening tasks. This is much related to listening effort or "the mental exertion required to attend to and understand an auditory message" (McGarrigle, et al., 2014, p. 2). The mental effort/investment a certain activity demands from the individual in the process of analyzing the data is related to the cognitive load of that activity. The cognitive load itself can be influenced by the way working memory processes information during doing different types of learning tasks designed and executed by curriculum designers based on a variety of instructional approaches and teaching methodologies. This aspect of listening comprehension is in need of further study as reviewing the literature shows that educational research on listening has mainly focused on cognitive and metacognitive aspects of listening and the way listening strategies are deployed to probe into the characteristics of successful listeners. Within the cognitive arena, the main focus seems to be mainly on bottom-up and topdown processes (Santos \& Gramah, 2018) and their interplay; and other aspects of cognition during listening comprehension (such as the role of long term memory and working memory) have just recently attracted the attention of language educationists and researchers. Considering the laborious nature of listening for foreign language learners, the incorporation of emergent theories into examining the reasons behind this struggle is justified.

This study addresses the issue of cognitive load of listening activities of a cognitive-based listening instruction that is designed to fulfil the requirements of a recently changed national curriculum. The listening section of the textbook has been developed and is taught based on the cognitive approach that intends to promote comprehension of the aural input. Both listening and reading comprehension sections function as the comprehensible and meaningful input as the course is designed based on Nation's proposition of four strands (Nation, 2007). The textbook has been taught from the academic year 2018 in English classes nationwide. The examination of the CL of this book would inform listening researchers and materials developers on the accuracy of the alignment of theory and practice and if precautions taken to make listening materials less challenging at the planning phase of a syllabus would be fruitful at the implementation phase in the classroom.

Besides examining the general CL of the listening activities, gender differences in CL are also considered in the study. The reason of this is twofold. First, while working memory structure and mechanisms have been found to be different across gender in neurology (Voyer, Voyer, \& Saint-Aubin, 2017), empirical and applied studies on the role of such differences in curriculum development are scarce (Chang \& Yang, 2010). Addressing this important issue by curriculum developers and materials designers would lead to the development of instructional materials that are at the cognitive level of the learners and can raise students' motivation and sustained effort. Second, although there is satisfactory number of research on differences between male and female language listeners' cognitive profile such as cognitive strategies (e.g., Sobhani, 2015) and information processing preferences (e.g., Bacon, 1992), the role gender plays in CL of listening activities is open to further research. Elaborating on the cognitive processes involved in listening comprehension from the perspective of CL theory considering learners' demographic variables such as gender would deepen researchers' understanding of the nature of this challenging process and let practitioners expand their insights on the reasons why listening is so difficult for foreign language learners. This directs the attention of the researchers to the importance of the way listening tasks are developed and integrated in the curriculum (e.g., Sweller, 2017) to help diverse people benefit from the listening instruction rather than just focusing on the role of teaching listening methodology in easing the listening process (e.g., Goh, 2000).

The main research questions of the study thus are:

1. How do students evaluate the cognitive load of listening activities of a cognitive-based listening instruction?

2. Is there a significant difference between male and female students' cognitive load of listening activities? 
3. What are the main sources of the difficulty of listening activities of a cognitive-based listening instruction?

\section{Listening comprehension as a cognitive process}

Listening comprehension is the most implicit and unobservable language skill that demands extremely high cognitive load from foreign language learners. In the process of listening comprehension, the speech continues and the speaker(s) would not wait for the listener(s) to catch up with the flow of information that is uttered most of the time with normal rate of speech. Both listening and reading are considered to be receptive language skills, and thus the fuel of language acquisition as a source of comprehensible input (Nunan, 2003). Receiving information via written and aural input does not denote by any means the passivity on the part of the language learners. Listening comprehension involves at least four overlapping types of processing including neurological, linguistic, semantic and pragmatic (Rost, 2011) that demands lots of cognitive effort from language learners.

The very first step in understanding an oral message is receiving it in the form of sound waves via the auditory organs, ears. Then during the linguistic processing, the listener is required to decode the message by performing bottom up processing of linguistic information, and to focus on every details of the language input (Moley, 2001). This data-driven and "stimulus-driven" (Howard, 1983, p. 291) type of information processing is usually contrasted with topdown and "conceptually-driven" (Howard, 1983, p. 292) information processing. Top-down listening would be rewarding if the listeners understand the purpose of the message by paying attention to the contextual clues of the content and the setting and activate appropriate schematic knowledge. Schema is "a structure in semantic memory that specifies the general or expected arrangement of a body of information" (Carroll, 2008, p. 176).

While many researchers have underscored the advantages of top-down processing over bottom-up processing particularly in cognitive psychology, comprehension is reported to be mainly dependent on the integration of both processes. In other words, when misunderstanding takes place in a listening situation, 'what' is misunderstood is attributed to linguistic elements and the 'why' behind this misunderstanding is attributed to the flaws of the semantic processing (Rost, 2011). Furthermore, relying on one of these processes separately would hinder comprehension or lead to misunderstanding. Why the listener would prefer one process over the other depends on listeners' sociocultural (e.g. L1/L2 cultural differences, background knowledge) and individual factors (age, gender, language proficiency) as well as the difficulty of the listening task or its cognitive load (Rost, 2006). Cognitive load within listening research is mostly defined based on task difficulty (Brown, 1995), yet in psychology cognitive load is a much more complicated concept that has certain ties with human cognitive architecture and the way instructional designs are planned and implemented.

\section{Cognitive Load Theory and instructional design}

Cognitive load is generally defined as "a multidimensional construct representing the load imposed on the working memory during performance of a cognitive task" (Chen, et al., 2016, p. 4) in cognitive psychology. The implications of cognitive load theory in instruction have been extensively discussed in educational psychology (e.g. Sweller, Ayres, \& Kalyuga, 2011). Based on this theory, considering the architecture of human brain and the way working memory functions in processing different types of information and its capacity/duration and different types of cognitive loads imposed on working memory are of vital importance when instructional and learning tasks are designed.

In this framework, working memory "refers to the system or systems that are assumed to be necessary in order to keep things in mind while performing complex tasks such as reasoning, comprehension and learning" (Baddeley, 2010). While working memory has been assumed to be a unitary construct for many years, it is now believed to have different components/ processors for different types of information. Based on Baddeley's multicomponent model of working memory, working memory has four components: the phonological loop, the visuospatial sketchpad, the central executive, and the episodic buffer (Fig. 1) (Baddeley, 2007). The model portrays the capability/structure of working memory in processing multimodal input assuming that there are separate processors/channels for processing auditory/verbal input and visual/pictorial input. In other words, in cases where multimodal information with high cognitive load is processed, the cognitive load would be distributed among these two channels and thus the load of learning task may decline. However, the capacity of the processors/channels seems to be limited and finite number of items can be kept in each channel for limited period of time.

The implication of this model is of vital importance for listening instruction and the inherent difficulty of L2 listening comprehension. The task of listening comprehension of a foreign language is much more complex and difficult when it is compared with first language (L1) listening as L1 listening comprehension is regarded to be a biologically primary knowledge, the knowledge that is acquired without conscious effort and humans are biologically predisposed to develop (Sweller, 2017). The acquisition and development of this type of knowledge does not need any formal instruction and thus is mastered effortlessly (Sweller, Ayres, \& Kalyuga, 2011). Unlike biologically primary knowledge, biologically secondary knowledge includes the type of knowledge that is acquired for cultural reasons when the time comes as the human cognitive system is armed with the capability of processing an infinite range of biologically secondary knowledge (Sweller, 2017). 
It is worth attention that different types of cognitive load may be imposed on working memory, particularly in teaching/learning context as a result of instruction. There are three types of cognitive load: intrinsic, extraneous, and germane (Sweller, et al., 2011). Intrinsic cognitive load is related to the intrinsic nature of the information that is going to be acquired regardless of the instructional design. Extraneous load is related to manner by which the information is presented during learning activities and instructional design. Germane is related to the process during which schemata is modified or built in the long term memory.
Cognitive load is created when the load of the learning task passes the learners' capacity/duration of working memory. Considering these three types of loads, the one that can be controlled and needs further attention by teachers, materials developers and curriculum designers is the extraneous cognitive load, as this is the only load created as a result of the way the teaching material is presented. "Extraneous cognitive load should be reduced as far as possible, thus reducing working memory resources devoted to extraneous issues and increasing the availability of germane resources devoted to intrinsic cognitive load" (Sweller, et al., 2011, p. 58).

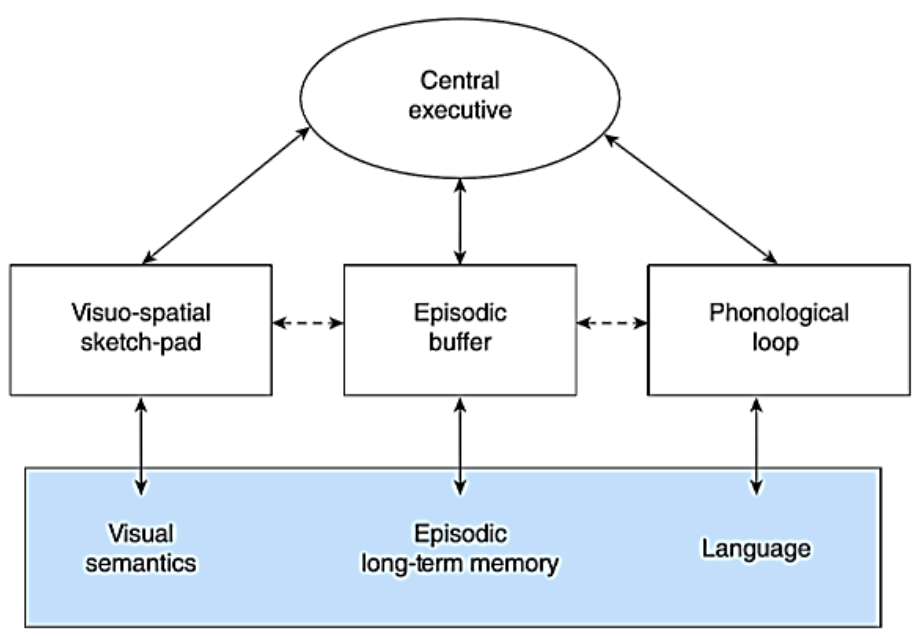

Figure 1. Multicomponent model of working memory (Baddeley, 2010).

The issue of cognitive load has gained a lot of attention since its conception in 1998 (Sweller, Van Merriënboer, \& Paas, 1998) and considerable studies have been carried out to consolidate the theoretical bases of the theory (e.g. Sweller, 2010; Sweller, 2019) and its instructional implications (e.g. Paas, Renkl, \& Sweller, 2004); and probe into the factors that can affect different types of CL (e.g., Cheon \& Grant, 2012). Language educationists in general and listening researchers in particular have also shown a surge of interest in cognitive load theory in recent years and have addressed the issue of cognitive processes of listening activities from this perspective.

Amichetti et al., (2013) examined the ability of listeners to monitor the capacity of working memory as new information arrived in real time. They found that listeners display good accuracy in deciding the time at which their highest span for correct recall of unstructured word lists has been arrived, and that there is a mismatch between correct moment-to-moment observing of available size surviving in working memory and memory span as evaluated in a plain baseline span test. In another study, Kim and Philips (2014) explored the cognitive correlates of listening in terms of inhibitory control, theory of mind, and comprehension monitoring after accounting for vocabulary and age. They recommended that to build the situation model, the capability to suppress irrelevant stimuli was an essential cognitive skill, and successful listening comprehension needs going beyond the meaning of particular words and sentences and perception of what the interlocutor says literally, understanding what he or she conveys (intention), and creating association among concepts.

Cognitive processing load across a wide range of listening conditions using pupillometry has been examined by Zekveld and Kramer (2014). They explored pupil response to speech masked by interfering speech across an intelligibility rates and concluded that the pupil response is sensitive to processing load, and possibly reflects cognitive overload in difficult conditions. Mattys, Barden, and Samuel (2014) explored if the extrinsic cognitive load generated by performing a nonlinguistic visual task while perceiving speech increases listeners' reliance on lexical knowledge and decreases their capacity to perceive phonetic detail. They reported that the perceptual sensitivity decreases (i.e., phoneme restoration increases) almost linearly with the effort involved in the concurrent visual task. However, cognitive load had only a minimal effect on the contribution of lexical information to phoneme restoration.

Learners' variables in the process of listening comprehension were investigated by Vandergrift and Baker (2015). Based on their findings they proposed a model in which general skills of auditory discrimination and working memory were initially important in listening comprehension that lead to more specific 
language skills (L1 and L2 vocabulary) in determining L2 listening comprehension. Similarly, Kim (2016) investigated component language and cognitive skills (i.e., working memory and attention) of listening comprehension and reported that listening comprehension is directly predicted by working memory, grammatical knowledge, inference, and theory of mind and is indirectly predicted by attention, vocabulary, and comprehension monitoring.

Mitterer and Mattys (2016) investigated the conditions under which cognitive load exerts an effect on the acuity of speech perception. The results suggested that speech perception is affected even by loads thought to be processed modularly, and that encoding in working memory might be the locus of interference. Also, Leahy and Sweller (2016) compared the cognitive load when the length and complexity of auditory and visual text instructions were manipulated. Their findings showed that in condition when multiple sources of information that refer to each other and cannot be understood in isolation are processed, presenting the information in an audiovisual format is beneficial if the verbal information is relatively simple and short. Recently, Farquharson and Jiang (2018) examined the extent to which working memory and behavioral attention predicted reading and listening comprehension and reported that working memory and behavioral attention were more important for listening than for reading and had direct effect on listening comprehension.

\section{The context of the study}

The contemporary history of language education in Iran has gone under six distinctive phases from 1850s to 2014 (Rahimi \& Alavi, 2017). The curriculum change that has been just completed in 2018 was designed and executed based on the country's National Fundamental Change Document (2011). The EFL curriculum consists of a six-year program and two book series entitled Prospect Series and Vision Series are in use for K7-K9 and K10-K12 respectively. The underlying framework of the curriculum is the communicative approach and the curriculum is developed based on the integration of four macro skills, emphasizing the use of language experiences in learning, providing learners with meaningful and comprehensible content, and promoting team spirit and collaboration.

The curriculum has been designed based on Nation and Macalister's (2010) model (Figure 2). Listening comprehension specifically functions as the comprehensible input and is placed as the first activity of the book after the introductory pages whose aim is to introduce the theme of the lesson. Considering listening and reading comprehension as the comprehensible input is based on the proposition of four strands organization of the materials meaning that "a course should include a roughly even balance of the four strands of meaningfocused input, language-focused learning, meaningfocused output and fluency activities" (Nation \& Macalister, 2010, p. 51).

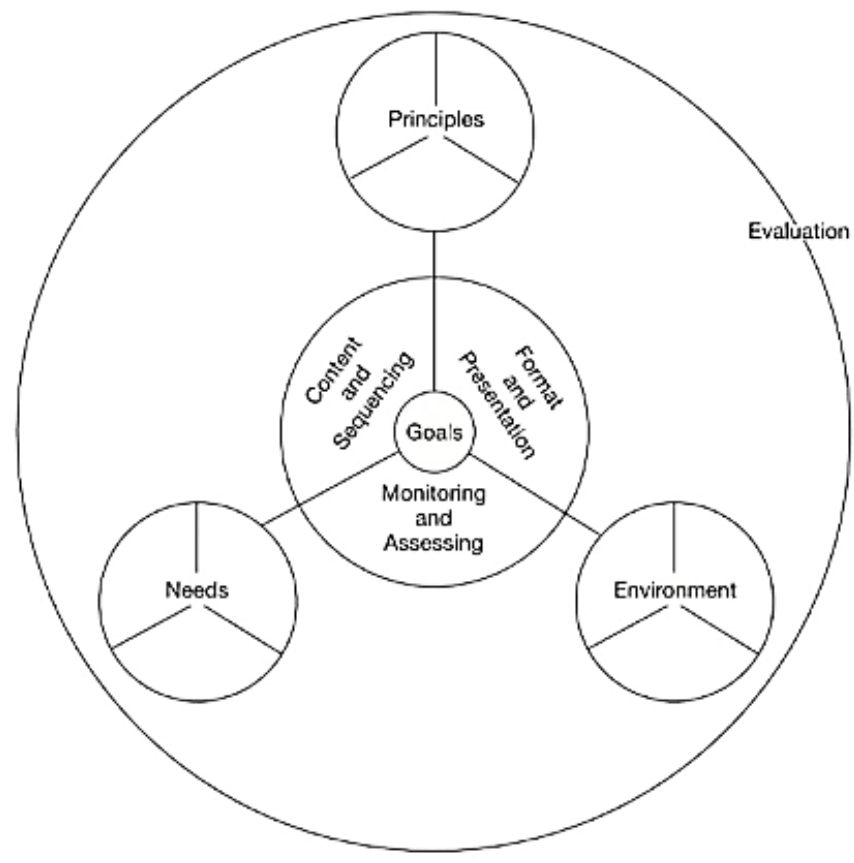

Figure 2. Nation and Macalister's model of the parts of the curriculum design process (2010, p. 3)

\section{METHOD}

\section{Respondents}

The participants of the study were $126 \mathrm{~K}-11$ students (62 male and 64 female students). They ranged in age between 15-16. The students were stuyding in the academic year 2018-2019 in the state schools of an urban area in Iran. The sample was selected based on convenience sampling. The study was carried out based on research guidelines of the Minsitry of Education (MOE) that allow and encourage teachers to do surveys in their classes on the MOE's research priorities, in this case the curriculum change and its challenges. 


\section{The instruments}

Two instruments were used to collect the required data of the study: CL measure to gather the quantitative data and an interview protocol to gather the qualitative data.

\section{CL measure}

Cognitive Load measure developed and validated by Leppink et al., (2013) was used to measure the cognitive load of listening activities of English book Vision 2 (Alavi Moghaddam, Kheirabady, Rahimi, \& Davari, 2017). The scale has 10 items and is anchored on a 10 Likert scale from 0 (not at all the case) to 10 (completely the case). The measure assesses three types of load including

- Intrinsic Load (items 1, 2,3)

- Extraneous Load (items 4, 5, 6)

- $\quad$ Germane Load (items 7, 8, 9, 10)

Reliability coefficients (i.e., Cronbach's alpha values) of the scale and its three components were estimated to be $.73, .80, .75$, and .82 respectively. The respondents were asked to fill in the $\mathrm{CL}$ measure immediately after doing the listening task in the class and judge the difficulty of the activity.

\section{The interviews}

In order to shed more lights on the findings of the quantitative study, 14 of the participants ( 6 male and 8 female students) who asserted to have problems with listening comprehension based on their completed CL measure took part in a structured and individual interview. During the interview the researcher followed a pre-prepared interview guide and asked 4 questions from the interviewees (Dörnyei, 2007). The questions of the interview revolved around 3 basic themes:

- challenges of listening activities,

- comparing the difficulty of listening comprehension and reading comprehension activities, and
- multimodality of the input.

The interview was a single-shut type and lasted about 10 to 15 minutes for each participant. Each student participated in the interview individually and fourteen interviews were conducted to gather the required information. The answers were tape-recorded and transcribed to be inserted into QDA miner. The interview questions are included in Appendix 1.

\section{RESULTS \\ Quantitative analysis}

Descriptive statistics were used to examine the cognitive load of listening activities (Table 1). As Table 1 shows, the general cognitive load of listening activities is rather high $(M=4.045)$, and when three kinds of CLs are compared, the GL (M=6.595, $\mathrm{SD}=2.342)$ is higher than IL $(\mathrm{M}=2.600, \mathrm{SD}=2.532)$ and EL ( $\mathrm{M}=2.089, \mathrm{SD}=2.379)$.

Further, in order to compare the CL of listening activities across gender, a one-way multivariate analysis of variance (MANOVA) was conducted in which three factors of CL scale served as the dependent variables and students' gender ( 2 levels: male and female) was the independent variable. The results from the Multivariate tests table for the main effect suggested that there was a statistically significant difference between two groups on the combined dependent variables (Wilks' $\mathrm{Lambda}=.424 ; \quad \mathrm{F}=55.178$; $p=.000<.001$; partial eta squared=.576). By applying Bonferroni adjustment to the alpha value $(.05 / 3=.017)$, when the results for the dependent variables were considered separately, two differences reached the statistical significance: IL and EL (Table 2). An inspection of the mean scores (Table 1) indicated that male students' mean on IL (mean=4.403, SD=2.318) and $\mathrm{EL}$ (mean=3.709, $\mathrm{SD}=2.351)$ are higher than those of female students (mean of $\mathrm{IL}=.854, \mathrm{SD}=1.106$ and mean of $\mathrm{EL}=.520, \mathrm{SD}=.892$ respectively).

Table 1. Descriptive statistics

\begin{tabular}{lcccccc}
\hline \multirow{2}{*}{ Variables } & \multicolumn{2}{c}{ Total $(\mathbf{n}=\mathbf{1 2 6})$} & \multicolumn{2}{c}{ Male $(\mathbf{n = 6 2})$} & \multicolumn{2}{c}{ Female $(\mathbf{n = 6 4 )}$} \\
\cline { 2 - 7 } & Mean & SD & Mean & SD & Mean & SD \\
\hline IL & 2.600 & 2.532 & 4.403 & 2.318 & .854 & 1.106 \\
EL & 2.089 & 2.379 & 3.709 & 2.351 & .520 & .892 \\
GL & 6.595 & 2.342 & 6.217 & 2.179 & 6.960 & 2.452 \\
Total CL & 4.045 & 1.531 & 4.921 & 1.502 & 3.196 & .990 \\
\hline
\end{tabular}

\section{Qualitative analysis}

In order to analyze the qualitative data, first the recordings of the interviews were transcribed and then coded. For careful coding, the researchers read the texts meticulously and took note of the related concepts to be able to define key words within three main themes. The transcribed text was then inserted into QDA Miner software (Version 4.0) for further analysis. Defining the codes for the software was done based on the main themes and the key words extracted from the transcripts during manual content analysis (Fig. 3). The texts were analyzed by the software and the findings were interpreted and discussed.

\section{Challenges of listening activities}

The students were asked to mention in detail what makes listening comprehension a difficult task. Seven students (five boys and two girls) think that the difficulty of listening comprehension activities is related to the rate of speech in the audio files and the way the words and sentences are pronounced.

They said that "those who speak in audio files talk so fast and vague.", and that "the rate of the audio file is 
high and I cannot understand it well". One boy specifically referred to the fact that "some of the pronunciations are vague" and one girl has related these two problems to teacher's methodology of teaching, "the rate of speaking in audio files is so high and the pronunciation of some words is unclear; our teacher does not pay attention to that and she cannot teach this part well”.

Table 2. Tests of between-subjects effects

\begin{tabular}{|c|c|c|c|c|c|c|c|}
\hline Source & $\begin{array}{c}\text { Dependent } \\
\text { Variable }\end{array}$ & $\begin{array}{c}\text { Type III Sum } \\
\text { of Squares }\end{array}$ & df & $\begin{array}{c}\text { Mean } \\
\text { Square }\end{array}$ & $\mathbf{F}$ & Sig. & $\begin{array}{c}\text { Partial Eta } \\
\text { Squared }\end{array}$ \\
\hline \multirow[t]{3}{*}{ Corrected Model } & $\mathrm{IL}$ & $396.668^{\mathrm{a}}$ & 1 & 396.668 & 121.482 & .000 & .495 \\
\hline & EL & $320.234^{b}$ & 1 & 320.234 & 102.439 & .000 & .452 \\
\hline & GL & $17.394^{\mathrm{c}}$ & 1 & 17.394 & 3.225 & .075 & .025 \\
\hline \multirow[t]{3}{*}{ Intercept } & IL & 870.446 & 1 & 870.446 & 266.578 & .000 & .683 \\
\hline & EL & 563.620 & 1 & 563.620 & 180.296 & .000 & .593 \\
\hline & GL & 5469.466 & 1 & 5469.466 & 1014.208 & .000 & .891 \\
\hline \multirow[t]{3}{*}{ gender } & IL & 396.668 & 1 & 396.668 & 121.482 & .000 & .495 \\
\hline & EL & 320.234 & 1 & 320.234 & 102.439 & .000 & .452 \\
\hline & GL & 17.394 & 1 & 17.394 & 3.225 & .075 & .025 \\
\hline \multirow[t]{3}{*}{ Error } & IL & 404.892 & 124 & 3.265 & & & \\
\hline & EL & 387.635 & 124 & 3.126 & & & \\
\hline & GL & 668.713 & 124 & 5.393 & & & \\
\hline \multirow[t]{3}{*}{ Total } & IL & 1653.667 & 126 & & & & \\
\hline & EL & 1258.222 & 126 & & & & \\
\hline & GL & 6166.750 & 126 & & & & \\
\hline \multirow[t]{3}{*}{ Corrected Total } & IL & 801.560 & 125 & & & & \\
\hline & EL & 707.869 & 125 & & & & \\
\hline & GL & 686.107 & 125 & & & & \\
\hline
\end{tabular}

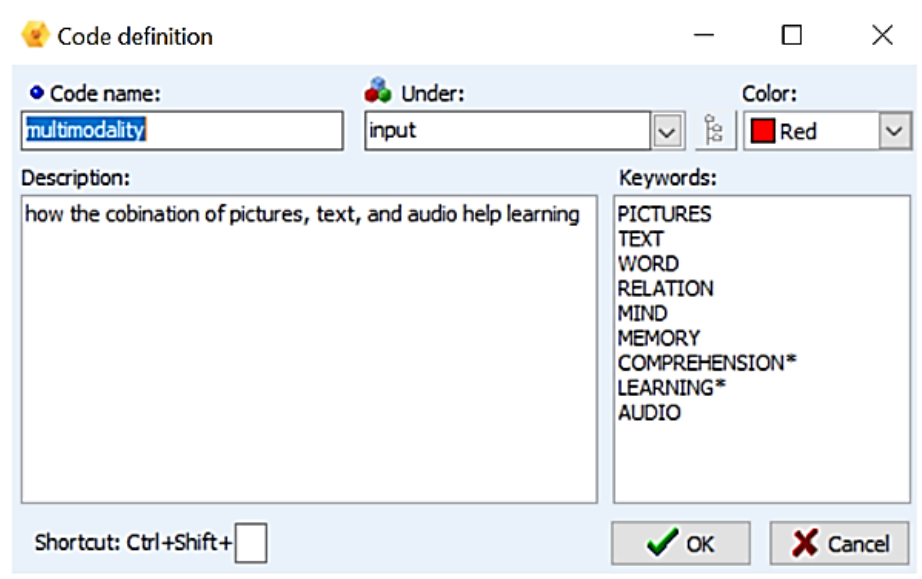

Figure 3. Sample of hierarchy of codes in QDA Miner

Lack of the required technology for listening instruction was raised to be one main problem in understanding the audio files by one boy, "there is not any language lab in our school to use and understand audio files better; some of the pronunciations are so difficult." Another boy also referred to the issue of the development of listening skills from K7-K9, "during the secondary school period we did not pay any attention to listening so it is more difficult than other skills for us; because it is new".

\section{Listening comprehension vs. reading comprehension} In the first part of the question the students were asked to compare the difficulty of listening and reading comprehension activities. Almost all girls and one boy said that listening comprehension activities are more difficult than reading comprehension activities. The absence of the text is the main reason why listening comprehension is more difficult than reading comprehension as they believed that "we cannot see the text simultaneously when we listen to the audio files so it is difficult to understand". They seemed to be able to use reading strategies more in comparison to listening strategies and this strategy control has made reading easier for them, "reading is easier because we could read the text and guess the meaning of the words by the help of the words whose meaning we know".

In the second part of the question, they were asked if they prefer listening comprehension activities to reading comprehension activities. Two boys and two girls believed that listening comprehension activities are more attractive and interesting than reading comprehension activities because they are more goaloriented. Some of the answers were: "it is more practical so it is more attractive"; "it is very useful and interesting; "it helps us to communicate".

Some students attributed their lack of interest in listening to the difficulty of listening comprehension. 
They said: "no, because listening is difficult for me"; "no, listening is unclear and hard for me"; "no, I learn better when I see the text whereas in listening I cannot see the text so it is more difficult than reading for me".; "no, because I cannot understand the words while I am listening".

One student linked this lack of interest to the ultimate goal of learning English in high-school, that is university entrance exam: "no, because listening is not important for university entrance exam, and just reading, vocabulary and grammar are important".

\section{Multimodality of the input}

All students (but one) believed that pictures are helpful in understanding listening comprehension. The point that most of them referred to is the combination of text and pictures that increases their comprehension and learning and makes listening easier. They believed that "when pictures and texts come together, we understand the meaning better and the words are stored in our memory"; "definitely it is helpful, because I can guess the meaning by using the pictures".

Two students, however, think that some pictures are not related to the topics and thus are not helpful. They believed that "it is partially helpful but some pictures do not directly refer to the intended meaning; "it is not totally helpful because some pictures are not directly related to the concepts and topics."

The main findings of the qualitative data analysis can be summarized as follows:

- The main problem of students in listening comprehension is the speakers' rate of speech.

- The pronunciations of some words are unclear, incomprehensible and difficult.

- There is a need to technological devices such as language lab to teach listening comprehension.

- Listening comprehension is more difficult than reading comprehension.

- Students cannot use listening strategies to guess the meaning of the words.

- The goal of developing listening skills is important for students. Most students are interested in listening comprehension and have positive attitudes towards its role in communication. They are not interested in it if it is not a part of their ultimate goal of study, that is passing university entrance exam.

- The difficulty of listening comprehension and students' lack of interest in listening are interrelated.

- Appropriate combination of text, audio and pictures can result in better understanding and learning.

\section{DISCUSSION}

This study focused on investigating the cognitive load of listening activities of a cognitive-based instruction among male and female high school students. The study merits both quantitative and qualitative data analysis techniques and as a result the discussion section is organized in two separate parts that follow.

\section{Quantitative data analysis}

The findings of quantitative data analysis primarily revealed that Germane Load of listening comprehension section is high in compariosn to the values of Intrinsic and Extrinsic loads. When male and female students were compared, the GL of both of them was found to be high, therefore no significant difference was observed between the means based on the gender of the participants.

Germane load is a kind of CL that is related to working memory resources (Sweller, et al. 2011) and its high level is favourable as it is related to learning outcome (Cierniak, Scheiter, \& Gerjets, 2009). When this kind of load is high, it is assumed that the task is engaging and encourages students to cognitively invest in doing the activity. Germane Load has been found to be related to the familiarity of the learning topic (Leppink et al., 2013) and the schemata that is activated or constructed during doing the task (Sweller, Van Merriënboer, \& Paas, 1998). As a result, the high GL of listening comprehension section in this study shows that the listening task of the textbook is at the level of students' comprehension level and lacks element interactivity or the complexity that "depends on a combination of both the nature of the information and the knowledge of the person processing the information" (Sweller, Van Merrienboer, \& Paas, 2019, p. 3).

One reason why students felt more engaged in listening task is the way the textbook is designed to make students familiar with the topic of the listening comprehension. Each lesson of Vision 2 has a central theme, and all macro skills activities (reading, listening, speaking and writing) are related to the same theme. Listening comprehension comes after three activities that aim at activating students' background knowledge on the topic of the lesson (Alavi Moghaddam, et al., 2017):

- The Title Page: consisting of four interesting facts about the main theme of the lesson

- The Impact Page: consisting of four pictures related to the theme of the lesson

- Get Ready: consisting of three to four activities to familiarize students with the theme, review previously-learned words or introduce some new words related to the topic of the lesson.

Therefore, before beginning the conversation part, the students' schemata is activated and they can predict the content of the conversation. These activities are followed by Conversation that itself consists of the following sections: Word Bank, Introduction, Conversation, and Questions. The Word Bank and Introduction give specific information about the Conversation and prepare the ground ready for the listening activity. This actually provides a perfect 
condition for meaningful input as based on Nation's four strands proposition learning through listening takes place when "only a small proportion of the language features are unknown to the learners. In terms of vocabulary, $95-98 \%$ of the running words should be within the learners' previous knowledge" (Nation, 2007, p. 3).

It is noteworthy to mention that, the methodology of teaching Conversation according to the Teacher's Guide of the book is based on a comprehension-based model within communicative language teaching approach including a three-phase cycle of pre-listening, while-listening and post-listening (Alavi Moghaddam, et al., 2017). In this model, activating the background knowledge of the listeners before the task and checking students' comprhension during and after the task are of vital improtance. Therefore, the high Germane Load of this section of the book can be attributed to the way the activities demand schemata activation and the efforts students bring to the task to process the aural information.

In other words, the organization of the materials from simple to complex and more familiar to less familar and the instructional intervention help students process the input by activating their schemata and building the new one without much cognitive load. This may lower intrinsic load as intrinsic load has been found to be inversely correlated with germane load (Lange \& Costley, 2018). Based on Cognitive Load Theory, this load is created by the interaction between instructional materials and the learners' level of expertise. In other words, element interactivity and processing different elements at the same time in working memory have a great role in intrinsic load. As it was mentioned, the organization of the materials in Vision 2 has managed the IL, but it is not zero. Intrinsic load is a function of the difficulty of the subject and as some subject matters such as L2 listening are intrinsically more difficult (Sweller, 2017) instructional designers should deploy some strategies to manage this type of load. As for Vision 2, it seems that the textbook is rather successful in fulfilling this goal. This finding also supports the fact that the cognitive aspects perform a key function in semantic comprehension (James, Krishnan, \& Aydelott, 2014) and that listening comprehension relys heavily on listeners' cognitive skill and multiform language; and that there is a necessaity to activate students' background knowledge prior to listening tasks.

Further, it was found that EL of listening activities is rather low. EL is a type of cognitive load that is determined by the way the input is presented and what learners should do during the learning task (Sweller, Van Merrienboer, \& Paas, 2019). EL can be manipulated by method of teaching and instructional interventions. As comprehension-based listening instrcution focuses on activating listeners' schemata through pre-listening activities and excalating cognitive effort throughout while-listening and post-listening phases, it decreases element interactivity and thus reduces EL (Sweller, et al., 2019). This supports the effectiveness of communicative language teaching methodology in teaching listening comprehension that not only underscores schemata activitation but also the "importance of practising core listening skills, such as listening for details, listening for gist, predicting, listening selectively and making inferences" (Goh, 2008 , p. 3). It seems that communicative approach provides learning conditions for language listeners that is in harmony with human cognitive architecture as it focuses on certain types of activities that can free working memory capacity (Paas, Renkl, \& Sweller, 2004). However, more research is required to shed lights on this issue and compare the impact of different types of listening instrcution on managing IL and reducing EL.

In addition, comparing IL and EL of girls and boys shows that girls perceived the IL and EL of the listening activity to be lower in comparison to boys. This corroborates the findings of some studies showing that male learners are better in doing visuospatial tasks while females are better at verbal and memory tasks (Bevilacqua, 2017); and that functional differences in doing verbal tasks are smaller between the two cerebral hemispheres in women in comparison to men (e.g., Kimura, 1992). This latter proposition itself is related to the fact that phonemic mismatch is especially processed in left hemisphere in male subjects, but in female subjects bilateral processing happened (Ikezawa et al., 2008). Since listening is a verbal task, it can be concluded that female students invest less mental effort in doing these types of activities as they use both sides of their brain for data processing and as a result listening would be easier for them. There is however a need to follow-up studies on this topic, since these differences are found to be a function of cognitive maturity and as the participants of the study were teenagers, different results may be gained among adult language learners.

\section{Qualitative data analysis}

It was primarily found that students' main problem with listening comprehension is the rate of speech; and unclear and incomprehensible pronunciation of the speakers. Pronunciation has been found to be as the most important component in language ego and difficult to acquire in a new language (Jiang \& Cohen, 2018). The role of pronunciation in the process of communication is undeniable. Therefore, teaching pronunciation rules and implementing pronunciation practices could help learners to understand audio files more effectively and decrease the chance of frustration among students while imposing lower amount of CL on them. One main problem with books of K7 to K9, the Prospect Series that are taught before Vision Series, is that they do not teach pronunciation systematically and based on new approaches. Incorporating practice-driven pronunciation instructions such as Lingua Franca Core (LFC) syllabus into teaching pronunciation would guarantee more intelligibility and comprehensibility among EFL learners (Rahimi \& Ruzrokh, 2016). 
It was also found that the development of listening skills from secondary school is an issue for students who have problems with listening comprehension. The students are not armed with the listening strategies such as inferencing or predicting the content, while they seem to be able to do that when they are reading. Very related to this finding is that the participants believed that listening comprehension is more difficult than reading comprehension as they cannot see the transcripts. While the Vison Series has focused on teaching reading strategies, it has to some extent neglected teaching listening strategies and as a result students are handicapped in deploying these strategies. This high dependence on cognitive system causes "effortful listening" which generates fatigue (PichoraFuller et al, 2016) and frustration among students. The importance of students' awareness and use of listening strategies to make students more skillful listeners, more motivated (Vandergrift, 2004), and more self-regulated (Rahimi \& Abedi, 2015) is evident. Therefore, incorporation of strategy-based instruction into teaching listening comprehension section is recommended. This, however, opens a line of research to scrutinize the effects of cognitive and metacognitive listening instruction on lowering the cognitive load of listening activities.

The students believed that appropriate combination of text, audio and pictures can result in better understanding of the aural input and that multimodality of the input can help them tackle their problems with listening comprehension. This result is supported by active processing (Mayer, 2009) in which learners' concentration on interconnected data and integrated data with former knowledge help learning. The amount of CL of listening activities is higher when separate data integrate into each other in comparison with multimodal presentations of data that impose lower CL. This finding can also be supported by dual channel theory (Mayer \& Moreno, 2003; Paivio, 1986) as students integrate verbal and non-verbal information provided for them during the reading activities while this opportunity has not been provided for listening part, so listening comprehension is more difficult than reading comprehension. Listening part of the book includes fewer pictures in comparison to reading part, so fewer opportunities for integrating visual and auditory information exist in listening section. As a result, changing the textbook within this framework is of primary importance. Providing pictures related to the content of listening and creating more attractive typography would facilitate listening comprehension and make it more interesting.

Teaching techniques and methodology of the teacher such as using a language lab was an issue for students as well. Based on previous studies, providing listeners with the skills required for carrying out listening activities (Goh \& Taib, 2006; Graham, Santos, \& Vanderplank, 2008) and technology-based instruction by considering students' learning styles (Ocepek, Bosnic, Nancovska Šerbec, \& Rugelj, 2013) could help students in carrying out their listening activities better. Lack of providing necessary infrastructures in alignment with the requirements of teaching approaches (such as communicative approach) where big-size curriculum change takes place- like the context of this study- would create lots of problems for both students and teachers.

Most students were found to be interested in listening comprehension and had positive attitudes towards its role in communication. They are not interested in listening, however, if it is not a part of their ultimate goal of study: passing the university entrance exam. Reading, grammar and vocabulary are the most important factors in university entrance exam of Iran and if the curriculum designers intend to provoke students to improve their listening skills, they have to add oral sections to nationwide gatekeeping exams. It was also found that the difficulty of listening comprehension and students' lack of interest in listening are interrelated. It is evident that diversities in interactive elements and task complexities increase the amount of IL and when the amount of task complexity increases students show less interest in learning (Ayres, 2006; Schnotz \& Kürschner, 2007).

\section{REFERENCES}

Alavi Moghaddam, S. B., Kheirabady, R., Rahimi, M., \& Davari, S. (2017). English for Schools: Vision 2. Tehran, Iran: Ministry of Education.

Amichetti, N.M., Stanley, R.M., White, A.G., \& Wingfield, A. (2013). Monitoring the capacity of working memory: Executive control and effects of listening effort. Memory \& cognition, 41(6), 839849. doi: 10.3758/s13421-013-0302-0

Ayres, P. (2006). Using subjective measures to detect variations of intrinsic load within problems. Learning and Instruction, 16(5), 389-400. doi: 10.1016/j.learninstruc.2006.09.001

Bacon, S. M. (1992). The relationship between gender, comprehension, processing strategies, and cognitive and affective response in foreign language listening. Modern Language Journal, 76(2), 41-56. doi: 10.1111/j.15404781.1992.tb01096.x

Baddeley, A. (2010). Working memory. Current Biology, 20(4), R136-R140. doi: 10.1016/j.cub.2009.12.014

Baddeley, A. (2007). Oxford psychology series (Vol. 45), Working memory, thought, and action. New York, US: Oxford University Press.

Bevilacqua, A. (2017). Commentary: Should gender differences be included in the evolutionary upgrade to cognitive load theory? Educational Psychology Review, 29(1), 189-194. doi: 10.1007/s10648-016-9362-6

Brown, A. (1995). The effect of rater variables in the development of an occupation specific language performance test. Language Testing, 12(1), 1-15. doi: 10.1177/026553229501200101

Carroll, D.W. (2008). Psychology of language. US: Thomson Wadsworth. 
Cierniak, G., Scheiter, K., \& Gerjets, P. (2009). Explaining the split-attention effect: Is the reduction of extraneous cognitive load accompanied by an increase in germane cognitive load? Computers in Human Behavior, 25(2), 315324. doi: 10.1016/j.chb.2008.12.020

Chang, C. C., \& Yang, F. Y. (2010). Exploring the cognitive loads of high-school students as they learn concepts in web-based environments. Computers \& Education, 55(2), 673-680. doi: 10.1016/j.compedu.2010.03.001

Chen, F., Zhou, J., Wang, Y., Yu, K., Arshad, S, Z., Khawaji, A., \& Conway, D. (2016). Robust multimodal Cognitive Load measurement. Switzerland: Springer.

Cheon, J., \& Grant, M. (2012). The effects of metaphorical interface on germane cognitive load in Web-based instruction. Educational Technology Research Development, 60(3), 399420. doi: 10.1007/s11423-012-9236-7

Chon, Y. V., \& Shin, T. (2019). Profile of second language learners' metacognitive awareness and academic motivation for successful listening: A latent class analysis. Learning and Individual Differences, 70(1), 62-75. doi: 10.1016/j.lindif.2019.01.007

Dörnyei, Z. (2007). Research methods in Applied Linguistics: Quantitative, qualitative and mixed methodologies. Oxford: Oxford University Press.

Farquharson, K., \& Jiang, H. (2018). Are working memory and behavioral attention equally important for both reading and listening comprehension? A developmental comparison. Reading and Writing, 31(7), 1449-1477. doi: 10.1007/s11145-018-9840-y

Goh, C. (2000). A cognitive perspective on language learners' listening comprehension problems. System, 28(1), 55-75. doi: 10.1016/S0346251X(99)00060-3

Goh, C. (2008). Metacognitive instruction for second language listening development: Theory, practice and research implications. RELC Journal, 39(2), 188-213. doi: 10.1177/0033688208092184

Goh, C., \& Taib, Y. (2006). Metacognitive instruction in listening for young learners. ELT Journal, 60(3), 222-232. doi: 10.1093/elt/ccl002

Graham, S., Santos, D., \& Vanderplank, R. (2008). Listening comprehension and strategy use: A longitudinal exploration. System, 36(1), 52-68. doi: 10.1016/j.system.2007.11.001

Herron, C. \& Seay, I. (1991). The effect of authentic aural texts on student listening comprehension in the foreign language classroom. Foreign Language Annals, 24(1), 487-495. doi: 10.1111/j.19449720.1991.tb00495.x

Hornsby, B. (2013). The effects of hearing aid use on listening effort and mental fatigue association with sustained speech processing demands. Ear and Hearing, 34(5), 523-534. doi: 10.1097/AUD.0b013e31828003d8
Howard, D. (1983). Cognitive psychology: Memory, language and thought. New York: Macmillian.

Ikezawa, S., Nakagome, K., Mimura, M., Shinoda, J., Itoh, K., Homma, I., \& Kamijima, K. (2008). Gender differences in lateralization of mismatch negativity in dichotic listening tasks. International Journal of Psychophisiology, 68(1), 41-50. doi: 10.1016/j.ijpsycho.2008.01.006

Fundamental Change Document. (2011). Tehran: Ministry of Education.

James, P. J., Krishnan, S., \& Aydelott, J. (2014). Working memory predicts semantic comprehension in dichotic listening in older adults. Cognition, 133(1), 32-42. doi: 10.1016/j.cognition.2014.05.014

Jiang, X., \& Cohen, A. D. (2018). Learner strategies for dealing with pronunciation issues in Mandarin. System, 76(1), 25-37. doi: 10.1016/j.system.2018.04.012

Kim, Y.-S., \& Phillips, B. (2014). Cognitive correlates of listening comprehension. Reading Research Quarterly, 49(3), 269-281. doi: 10.1002/rrq.74

Kim, Y.-S. G. (2016). Direct and mediated effects of language and cognitive skills on comprehension or oral narrative texts (listening comprehension) for children. Journal of Experimental Child Psychology, 141(1), 101-120. doi: 10.1016/j.jecp.2015.08.003

Kimura, D. (1992). Sex differences in the brain. Scientific American, 267(1), 119-125.

Lange, C. \& Costley, J. (2018). The moderating effects of intrinsic load on the relationship between selfregulated effort and germane load. Journal of Computer Assisted Learning, 34(6), 652-660. doi: 10.1111/jcal.12269

Lau, K-L. (2017). Strategy use, listening problems, and motivation of high- and low-proficiency Chinese listeners. Journal of Educational Research, 110(5), 503-514. doi: 10.1080/00220671.2015.1134421

Leahy, W., \& Sweller, J. (2016). Cognitive load theory and the effects of transient information on the modality effect. Instructional Science, 44(1), 107123. doi: 10.1007/s11251-015-9362-9

Leppink, J., Paas, F., Van der Vleuten, C.P.M., Van Gog, T., \& Van Merriënboer, J, J, G. (2013). Development of an instrument for measuring different types of cognitive load. Behavior Research Methods, 45(4), 1058-1072. doi; 10.3758/s13428-013-0334-1

Martínez-Flor, A., \& Usó-Juan, E. (2006). A comprehensive pedagogical framework to develop pragmatics in the foreign language classroom: The 6Rs approach. Applied Language Learning, 16(2), 39-64.

Mattys, S. L., Barden, K., \& Samuel, A. G. (2014). Extrinsic cognitive load impairs low-level speech perception. Psychonomic Bulletin \& Review, 21(3), 748-754. doi: 10.3758/s13423-013-0544-7

McGarrigle, R., Munro, K. J., Dawes, P., Stewart, A. J., Moore, D.R., Barry, J.G., \& Amitay, S. (2014). 
Listening effort and fatigue: What exactly are we measuring? International Journal of Audiology, 53(7), 433-440. doi: 10.3109/14992027.2014.890296.

Mitterer, H., \& Mattys, S. L. (2016). How does cognitive load influence speech perception? An encoding hypothesis. Attention, Perception \& Psychophysics, 79(1), 344-351. doi: 10.3758/s13414-016-1195-3

Mayer, R. E., \& Moreno, R. (2003). Nine ways to reduce cognitive load in multimedia learning. Educational Psychologist, 38(1), 43-52. doi: 10.1207/S15326985EP3801_6

Mayer, R. E. (2009). Multimedia learning (2nd ed.). Cambridge: Cambridge University Press.

Moley, J. (2001). Aural comprehension instruction: Principles and practices. In: Celce-Murcia, M. (Ed.), Teaching English as a second or foreign language (pp. 69-85). US: Heinle and Heinle.

Nation, P. (2007). The four strands. International Journal of Innovation in Language Learning and Teaching, 1(1), 2-13. doi: 10.2167/illt039.0

Nation, I. S. P., \& Macalister, J. (2010). Language curriculum design. New York, NY: Routledge

Nunan, D. (2003). Practical English Language Teaching. Boston: McGraw Hill.

Ocepek, U., Bosnic, Z., Nancovska Šerbec, I., \& Rugelj, J. (2013). Exploring the relation between learning style models and preferred multimedia types. Computers \& Education, 69(1), 343-355. doi: 10.1016/j.compedu.2013.07.029

Paas, F., Renkl, A., \& Sweller, J. (2004). Cognitive load theory. Instructional Science, 32(1), 1-2. doi: 10.1023/b:truc.0000021806.17516.d0

Paivio, A. (1986). Mental representations: A dual coding approach. Oxford, England: Oxford University Press.

Pichora-Fuller, M. K., Kramer, S. E., Eckert, M. A., Edwards, B., Hornsby, B. W., Humes, L. E., et al. (2016). Hearing impairment and cognitive energy: The framework for understanding effortful listening (FUEL). Ear and Hearing, 37(1), 5-27. doi: 10.1097/AUD.0000000000000312.

Rahimi, M., \& Abedi, S. (2015). The role of metacognitive awareness of listening strategies in listening proficiency: The case of language learners with different levels of academic selfregulation. In A. Pena-Ayala (Ed.), Metacognition: fundamentals, applications, and trends (pp. 169192). Switzerland: Springer.

Rahimi, M., \& Alavi, J. (2017). The role of teaching experience in language teachers' perceptions of a top-down curriculum change. Curriculum Journal, 28(4), 479-503. doi:

10.1080/09585176.2017.1344134

Rahimi, M., \& Ruzrokh, S. (2016). The impact of teaching Lingua Franca Core on English as a foreign language learners' intelligibility and attitudes towards English pronunciation. Asian
Englishes, 18(2), 141-156. doi: $10.1080 / 13488678.2016 .1173466$

Rost, M. (2006). Areas of research that influence L2 listening instruction. In E. Uso-Juan \& A. Martinez-Flor (Eds.), Current trend in the development and teaching of the four language skills (pp. 47-74). Berlin: Mounton de Gruyter.

Rost, M. (2011). Teaching and researching listening (2nd ed). London: Longman.

Santos, D., \& Graham, S. (2018). What teachers say about listening and its pedagogy: A comparison between two countries. In A. Burns and J. Siegal (Eds.), International perspectives on teaching the four skills in ELT: Listening, speaking, reading, writing (pp. 21-35). Switzerland: Palgrave Macmillan.

Schnotz, W., \& Kürschner, C. (2007). A reconsideration of cognitive load theory. Educational Psychology Review, 19(4), 469-508. doi: 10.1007/s10648-007-9053-4

Sobhani, Z. (2015). An investigation into the relationship between gender and cognitive listening comprehension strategies. JIEB, 3(1), 4750.

Sweller, J. (2010). Element interactivity and intrinsic, extraneous, and germane cognitive load. Educational Psychology Review, 22(2), 123-138. doi: 10.1007/s10648-010-9128-5

Sweller, J. (2017). Cognitive load theory and teaching English as a second language to adult learners. TESL Ontario, Contact Magazine, 1-10. Retrieved from contact.teslontario.org/wpcontent/uploads/2017/05/SwellerCognitiveLoad.pdf

Sweller, J., Ayres, P., \& Kalyuga, S. (2011). Cognitive load theory. New York: Springer.

Sweller, J., Van Merriënboer, J. J. G., \& Paas, F. G. W. C. (1998). Cognitive architecture and instructional design. Educational Psychology Review, 10(3), 251-296. doi: 10.1023/a:1022193728205

Sweller, J., Van Merrienboer, J. J. G., \& Paas, F. (2019). Cognitive architecture and instructional design: 20 years later. Educational Psychology Review, 31(2), 261-292. doi: 10.1007/s10648-01909465-5

Vandergrift, L., (1999). Facilitating second language listening comprehension: Acquiring successful strategies. ELT Journal, 53(3), 168-176. doi: 10.1093/elt/53.3.168

Vandergrift, L. (2004). Learning to listen or listening to learn? Annual Review of Applied Linguistics, 24(1), 3-25. doi: 10.1017/S0267190504000017

Vandergrift, L. (2007). Recent developments in second and foreign language listening comprehension research. Language Teaching, 40(3), 191-210. doi: 10.1017/S0261444807004338

Vandergrift, L., \& Baker, S. (2015). Learner variables in second language listening comprehension: An exploratory path analysis. Language Learning, 65(2), 390-416. doi: 10.1111/lang.12105 
Voyer, D., Voyer, S.D. \& Saint-Aubin, J. (2017). Sex differences in visual-spatial working memory: A meta-analysis. Psychonomic Bulletin \& Review, 24(2), 307-334. doi: 10.3758/s13423-016-1085-7

Worthington, D. L., \& Bodie, G. D. (2018). Defining listening: A historical, theoretical, and pragmatic assessment. In D. L. Worthington and G. D. Bodie (Eds), The sourcebook of listening research:
Methodology and measures (pp. 3-18). US: Wiley Blackwell.

Zekveld, A. A., \& Kramer, S. E. (2014). Cognitive processing load across a wide range of listening conditions: insights from pupillometry. Psychophysiology, 51(3), 277-284. doi: 10.1111/psyp. 12151

\section{APPENDIX}

\section{Interview Questions}

Theme 1: Challenges of listening activities

1. Please mention in details your main problems with listening comprehension activities.

Theme 2: Listening comprehension vs. reading comprehension

2. Do you think listening comprehension activities are easier than reading comprehension activities?

3. Do you think listening comprehension activities are more interesting than reading comprehension activities? Theme 3. Multimodality of the input

4. Do you think pictures help you understand listening tasks better? 